\title{
Lupus of the larynx: when bamboo nodes lead to diagnosis...
}

\author{
Jelena Todic, Igor Leuchter
}

Département des Neurosciences Cliniques, Hôpitaux Universitaires de Genève, Genève, Switzerland

Correspondence to Dr Jelena Todic, Jelena.Todic@hotmail.ch

Accepted 10 May 2018
To cite: Todic J, Leuchter I. BMJ Case Rep Published Online First: [please include Day Month Year] doi:10.1136/bcr-2017-

Check for updates

\section{DESCRIPTION}

An 18-year-old patient consulted complaining of dysphonia for 3 months associated with severe weakness, headache and diffuse articular pain, with haematoma at the slightest trauma.

Laryngoscopy showed a submucosal oval lesion in the middle third of the two vocal folds resembling bamboo joint nodes (figure 1). Laboratory analysis showed the presence of antinuclear antibodies, antidouble-stranded DNA, antinucleosome, anti-SSA (117), anti-SSB (115) and anti-Sm (25) antibodies associated with thrombocytopaenia, haemolytic anaemia and severe ADAMTS-13 deficiency (under 5\%). The patient was admitted to the hospital for monitoring, plasma exchange and glucocorticoid therapy. The diagnosis of systemic lupus erythematosus was made. The laryngeal lesions were bamboo nodes. The patient received Solu-Medrol $500 \mathrm{mg} /$ day and prednisone $60 \mathrm{mg} /$ day combined with speech therapy. The bamboo nodes partially regressed under treatment with a marked improvement of the voice. A few months later, laryngeal injection of triamcinolone $40 \mathrm{mg}$ under local anaesthesia was performed with a favourable response.

Bamboo nodes are rare but typical lesions of the vocal folds, mostly associated with an autoimmune disease. ${ }^{1}$ Hoarseness due to the vocal cord lesions may be the presenting symptom. They should be looked for in every patient with a diagnosis of autoimmune disease and who complains of dysphonia. ${ }^{2} 3$ Evolution under speech therapy and systemic steroids is frequently

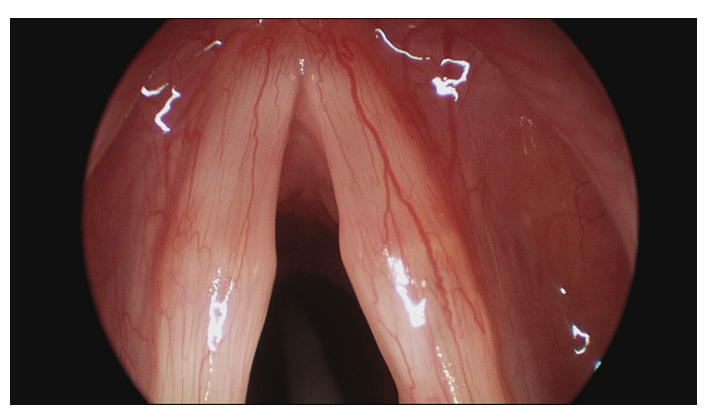

Figure 1 Direct laryngeal exam showing submucosal lesions in the middle third of the vocal folds.

\section{Learning points}

- All patients with bamboo nodes on the vocal folds should undergo an immunological check-up.

- All patients with autoimmune diseases complaining of dysphonia should have laryngoscopy.

- Bamboo nodes are rare but typical lesions of the vocal folds.

- Treatment includes speech therapy and corticosteroids.

favourable. Conservative treatment is preferred over surgical removal due to risk of scar and recurrence.

Contributors JT is the corresponding author and contributed to the acquisition of data and was directly in contact with the patient. She made her sign the consent. She also collected the patient's data, analysed them and wrote the text which accompanies the image. She designed the picture of the vocal folds to match the BMJ's criteria. She did a literature review. IL made the diagnosis of lupus erythematosus and saw the bamboo nodes on the vocal folds. He took the picture of the bamboo nodes when examining the larynx. He revised the written work critically and gave the final approval before submission. He participated in the design of the work.

Funding The authors have not declared a specific grant for this research from any funding agency in the public, commercial or not-for-profit sectors.

Competing interests None declared.

Patient consent Obtained.

Provenance and peer review Not commissioned; externally peer reviewed.

(c) BMJ Publishing Group Ltd (unless otherwise stated in the text of the article) 2018. All rights reserved. No commercial use is permitted unless otherwise expressly granted.

\section{REFERENCES}

1 Scarpelli DG, McCOY FW, Scott JK. Acute lupus erythematosus with laryngeal involvement. $N$ Eng/ I Med 1959;261:691-4.

2 Tsunoda K, Soda Y. Hoarseness as the initial manifestation of systemic lupus erythematosus. J Laryngol Otol 1996;110:478-9.

3 Murano E, Hosako-Naito Y, Tayama N, et al. Bamboo node: primary vocal fold lesion as evidence of autoimmune disease. J Voice 2001;15:441-50. 
Copyright 2018 BMJ Publishing Group. All rights reserved. For permission to reuse any of this content visit http://group.bmj.com/group/rights-licensing/permissions.

BMJ Case Report Fellows may re-use this article for personal use and teaching without any further permission.

Become a Fellow of BMJ Case Reports today and you can:

- Submit as many cases as you like

- Enjoy fast sympathetic peer review and rapid publication of accepted articles

Access all the published articles

- Re-use any of the published material for personal use and teaching without further permission

For information on Institutional Fellowships contact consortiasales@bmjgroup.com

Visit casereports.bmj.com for more articles like this and to become a Fellow 